\title{
Educational LPTK, Non-educational LPTK, and Non-LPTK Students' Intention to Become Teacher
}

\author{
Suyanta ${ }^{1, *}$, Muharram², Usman Mulbar ${ }^{2}$, Bakharani Rauf ${ }^{2}$, Muhammad Agung $^{2}$, Ganefri $^{3}$, \\ Hantje Ponto ${ }^{4}$, I Nyoman Sila ${ }^{5}$, Abdul Wahid ${ }^{2}$, Jumadi Mabe Parenreng ${ }^{2}$, Yasdin ${ }^{2}$, \\ Sri Rejeki Dwi Astuti ${ }^{1}$, Anggi Ristiyana Puspita Sari ${ }^{1}$, Rizki Arumning Tyas ${ }^{1}$ \\ ${ }^{1}$ Graduate School, Universitas Negeri Yogyakarta, Indonesia \\ ${ }^{2}$ Institute of Research and Community Services, Universitas Negeri Makassar, Indonesia \\ ${ }^{3}$ Department of Electricity Education, Universitas Negeri Padang, Indonesia \\ ${ }^{4}$ Department of Electricity Education, Universitas Negeri Manado, Indonesia \\ ${ }^{5}$ Department of Art and Design, Universitas Pendidikan Ganesha, Indonesia
}

Received August 27, 2020; Revised October 14, 2020; Accepted November 1, 2020

\section{Cite This Paper in the following Citation Styles}

(a): [1] Suyanta, Muharram, Usman Mulbar, Bakharani Rauf, Muhammad Agung, Ganefri, Hantje Ponto, I Nyoman Sila, Abdul Wahid, Jumadi Mabe Parenreng, Yasdin, Sri Rejeki Dwi Astuti, Anggi Ristiyana Puspita Sari, Rizki Arumning Tyas , "Educational LPTK, Non-educational LPTK, and Non-LPTK Students' Intention to Become Teacher," Universal Journal of Educational Research, Vol. 8, No. 12, pp. 6676 - 6683, 2020. DOI: 10.13189/ujer.2020.081232.

(b): Suyanta, Muharram, Usman Mulbar, Bakharani Rauf, Muhammad Agung, Ganefri, Hantje Ponto, I Nyoman Sila, Abdul Wahid, Jumadi Mabe Parenreng, Yasdin, Sri Rejeki Dwi Astuti, Anggi Ristiyana Puspita Sari, Rizki Arumning Tyas (2020). Educational LPTK, Non-educational LPTK, and Non-LPTK Students' Intention to Become Teacher. Universal Journal of Educational Research, 8(12), 6676 - 6683. DOI: 10.13189/ujer.2020.081232.

Copyright $\bigcirc 2020$ by authors, all rights reserved. Authors agree that this article remains permanently open access under the terms of the Creative Commons Attribution License 4.0 International License

\begin{abstract}
Teacher is seen as a profession that has a good image among the general public due to its power of influence. Intention to be a teacher is not just limited to pre-service students. Since the enactment of Permendikbud No 87 of 2013, non-pre-service students have a good chance of being teachers. This study aims to identify the intention difference to be a teacher among pre-service students and non-pre-service students in LPTK, also non-pre-service students in non-LPTK. A total of 98 pre-service and non-pre-service students studying chemistry education and chemistry at LPTK and non-LPTK in Yogyakarta were surveyed using a questionnaire. The sampling technique used is purposive sampling. The data was analyzed using One-way ANOVA by SPSS 20 to identify the hypothesis about the intention differences among the three groups. The study confirmed that there are differences between all three groups, which pre-service students at LPTK have big intentions, the second is non-pre-service students at LPTK, and the last is non-pre-service students at non-LPTK show a less intention.
\end{abstract}

Keywords LPTK, Intention, Teacher

\section{Introduction}

The era of industrial revolution 4.0 sparked intense competition in various sectors, not only in the education sector. The response arising from the industrial revolution era 4.0 in the education sector is the emergence of a term called education 4.0 or education 4.0 [10]. Education 4.0 aims to increase competitive human resources productivity. Therefore, all educational institutions from elementary schools to colleges compete against each other to produce superior and competitive graduates. To realize these goals, students are expected to have life skills in the form of global competencies or 21st century competencies including investigating symptoms, recognizing problems, communicating ideas, cooperation, creativity, and critical thinking [14, 22].

The success of students in fostering global competence cannot be separated from the role of a teacher. Although the learning plan is well organized and the learning facilities are well organized, the success of the learning process will not be achieved if it is not supported by a 
teacher's readiness to manage and control learning in the classroom. Teachers develop, study, and implement appropriate learning models to foster the global competencies of students. In addition, teachers are also required to use various learning media that suit the needs of the times. The fact that teacher's demands are getting bigger has been a concern for the government for the past 15 years. Various programs have been carried out by the government as a form of efforts to improve teacher competency, including teacher certification programs, teacher competency exams (UKG), and teacher profession programs (PPG) [1].

Universities are a major milestone in preparing and producing prospective professional teachers with high quality and quantity, especially educational institutions (LPTK). In language, LPTK is defined as Institute of Teacher Training. LPTK term in Indonesia is an institute/ university that organizes education for prospective teachers. Based on Law No. 14 of 2005, LPTK carries out the task of organizing teacher procurement programs as well as organizing and developing educational and non-educational sciences. LPTK must also develop the competencies required by a teacher to support the implementation of national education, international education, and local excellence-based education. The statement was reaffirmed in Permendikbud No. 22 of 2020, which stated that LPTK, as an institution synergizing with the Ministry of Education, has a national education development agenda in the form of improving quality and competitive human resources and mental revolution and cultural development.

The teacher obligation stipulated in PP No. 74 Article 2 of 2008 is mandatory to have academic qualifications, competencies, educator certificates, physical and spiritual health, and have the ability to realize national educational goals. Based on data obtained from the Ministry of Education, the number of certified teachers in 2019 rose by 39,480 from the previous year. The increase in the number of certified teachers indicates that LPTK has successfully scored competent teachers. Nevertheless, the fact still shows that many teachers are often shown to act as successors to knowledge, not as learning facilitators [27]. The statement supported research from Choy, Yim, and Sedhu [41] which stated that the teacher's perspective is more on getting recognition from supervisors that they perform their duties well as teachers, rather than reflecting on their teaching to improve their skill.

The number of S-1 graduates was 260,000 in 2016 and increased to 500,000 in 2018 [19], that prove the number of people who want to be a teacher is increasing. According to research conducted by Topkaya \& Uztosun [33] a student's interest in becoming a teacher is influenced by extrinsic and intrinsic motivations. Extrinsic motivation can be in the form of experience, definite working hours, and school holidays, while intrinsic motivation is in the form of confidence in good teaching ability and perception of the teacher profession. Therefore, interest cannot just arise in a person. Person's interest is reflected through his or her expression or deed that likes something, so that one has a tendency to point to a choice.

A person who has an intention to become an educator, tends to choose LPTK in order to develop the potential and competencies that teachers must have, namely, pedagogical, professional, personality, and social competencies. LPTK equips prospective graduates with field experience practice program (PPL) to make students' skills in teaching more felt. PPL is also one of LPTK strategies to be able to grow the competencies of pedagogy and professional students. Therefore, interest alone is not enough to form a student into a professional teacher. Nevertheless, interest is the main foundation that prospective students must have in order to develop and hone their skills. In addition, interest also plays an important role in determining the high level of learning achievement.

One's interests can be fickle due to various factors. One of them is the lecture process and programs run by LPTK students. After going through the learning process some students feel that the teacher is not a suitable field to pursue, but for other students the teacher is the right choice of profession. This extrinsic factor can affect the quality of a student's readiness to become a teacher. Declining interest in prospective teacher students can lead to an unprepared foray into education so that its credibility is doubtful, because pedagogical and professional competencies must be trained and developed consistently through the learning process [16].

After the enactment of Permendikbud No 87 of 2013, graduates of S-1 education is not the only candidate for teacher. Based on article 1 of the regulation, it is stipulated that non-educational S-1 graduates who have the interest and talent to become a teacher are allowed to participate in PPG in order to master the competence of the teacher in its entirety. With the permission for the graduates from non-LPTK universities to be able to participate in PPG, the competitiveness of students to become teachers is getting tighter. This regulation is certainly unsettling graduates of S-1 education who have struggled to develop their pedagogical competencies for 4 years. However, not all non-educational graduates are interested in becoming teachers, as are graduates of S-1 education who choose a career in the company.

The study of the problem has the potential to be analyzed more in-depth. Based on the background that has been presented, this research aims to know the difference in the interest of educational and non-educational students from LPTK as well as students from non-LPTK to become teachers.

\section{Methods}

The samples used in this study were 98 second-year students majoring in chemical education and chemistry 
majors from LPTK and non LPTK universities in Yogyakarta. The sampling technique used is purposive sampling technique because the sample is selected based on certain considerations, namely, based on the student's origin. Based on the origin of the study program and its university, the research sample was divided into three groups. First group include 22 students of non-LPTK Chemistry Program, second group include 38 students of LPTK Chemistry Program, and third group include 38 students of LPTK Chemical Education Program. This research was conducted in the even semester of the 2019/2020 school year.

The instruments used in this study are questionnaires of students' interest in becoming teachers. The poll consists of 50 statement items and uses the Likert Scale 4. The questionnaire was developed based on interest indicators and adapted to problems in the school environment.

The data obtained were analyzed using the SPSS 20 program. The SPSS 20 program is used to prove the reliability of polls, the validity of poll constructs, and test whether there is a difference in interest in being a teacher in the sample tested. Reliability tests are analyzed using reliability analysis tests based on Cronbach's alpha. Construct validity is analyzed using Exploratory Factor Analysis with component analysis extraction and varimax rotation principles [5, 34, 39]. Anova's One-way analysis was used to test research hypotheses on whether there was a difference in interest in being a teacher among the three sample groups. Here is the research hypothesis used in this study.

$\mathrm{H}_{0}: \mu_{1}=\mu_{2}=\mu_{3}$ (There was no difference in interest in being a teacher between the three groups)

$\mathrm{Ha}: \mu_{\mathrm{i}} \neq \mu_{\mathrm{j}}$ (There is a difference in interest in being a teacher between the three groups)

Furthermore, the Post Hoc test, Scheffe test, is conducted to find out which group has the highest interest in becoming teachers. Scheffe test is selected as a post hoc test because the Scheffe test is the appropriate method for a relatively small number of samples and the number of samples of each group is not the same [15, 36].

\section{Result and Discussion}

\subsection{Quesstionnaires Validity and Reliability}

A good research instrument must be valid and reliable. Therefore, the questionnaire used to collect data must be first analyzed its validity and reliability. Analysis of the validity of the questionnaire is used to find out if the statement in the poll is in accordance with the measurement objective which is to measure the interest and talent of the test takers. Prior to the interpretation of the results of the exploratory factor analysis, the sample adequacy interpretation was first performed using the Kaiser-Mayer-Olkin Measure of Sampling Adequacy
(KMO-MSA) and Bartlett's Test of Sphericity tests to test whether there was a correlation between variables. A sample is said to be sufficient for factor analysis if it has a KMO Coefficient exceeding Kaiser's criteria, which is 0.5 $[3,5,39]$. The KMO coefficient obtained is 0.720 , so the sample used is sufficient for factor analysis. Furthermore, the result of Bartlett's Test of Sphericity is 2586E3, $\mathrm{p}=0.00$. The results indicate that between statement items have a high correlation for factor analysis due to their significance level $\mathrm{p}<005 \quad[8,34]$. Therefore, the interpretation of the results of the analysis can be continued by the analysis of the validity of the instrument's construct with the analysis of exploratory factors.

Valid statement items or other items can be looked at the rotated component matrix output. Items are said to be valid if they have an anti-image correlation value of more than $0.4[5,8]$. The results of the analysis of the validity of the questionnaire of interest in becoming a teacher in the form of anti image correlation values are presented in Table 1.

Table 1. Table of Values Anti Image Correlation Questionnaire Interest in Becoming a Teacher

\begin{tabular}{|c|c|c|c|c|c|}
\hline No. & $\begin{array}{l}\text { anti image } \\
\text { corr. value }\end{array}$ & No. & $\begin{array}{l}\text { anti image } \\
\text { corr. value }\end{array}$ & No. & $\begin{array}{l}\text { anti image } \\
\text { corr. value }\end{array}$ \\
\hline 1 & $0,654^{\mathrm{a}}$ & 18 & $0,806^{\mathrm{a}}$ & 35 & $0,756^{\mathrm{a}}$ \\
\hline 2 & $0,682^{\mathrm{a}}$ & 19 & $0,756^{\mathrm{a}}$ & 36 & $0,758^{\mathrm{a}}$ \\
\hline 3 & $0,653^{\mathrm{a}}$ & 20 & $0,703^{\mathrm{a}}$ & 37 & $0,583^{\mathrm{a}}$ \\
\hline 4 & $0,540^{\mathrm{a}}$ & 21 & $0,771^{\mathrm{a}}$ & 38 & $0,432^{\mathrm{a}}$ \\
\hline 5 & $0,609^{a}$ & 22 & $0,826^{\mathrm{a}}$ & 39 & $0,846^{\mathrm{a}}$ \\
\hline 6 & $0,616^{\mathrm{a}}$ & 23 & $0,606^{\mathrm{a}}$ & 40 & $0,807^{\mathrm{a}}$ \\
\hline 7 & $0,713^{\mathrm{a}}$ & 24 & $0,708^{\mathrm{a}}$ & 41 & $0,757^{\mathrm{a}}$ \\
\hline 8 & $0,665^{\mathrm{a}}$ & 25 & $0,824^{\mathrm{a}}$ & 42 & $0,730^{\mathrm{a}}$ \\
\hline 9 & $0,445^{\mathrm{a}}$ & 26 & $0,808^{\mathrm{a}}$ & 43 & $0,617^{\mathrm{a}}$ \\
\hline 10 & $0,720^{\mathrm{a}}$ & 27 & $0,824^{\mathrm{a}}$ & 44 & $0,809^{\mathrm{a}}$ \\
\hline 11 & $0,782^{\mathrm{a}}$ & 28 & $0,483^{\mathrm{a}}$ & 45 & $0,769^{\mathrm{a}}$ \\
\hline 12 & $0,529^{a}$ & 29 & $0,555^{\mathrm{a}}$ & 46 & $0,784^{\mathrm{a}}$ \\
\hline 13 & $0,603^{\mathrm{a}}$ & 30 & $0,850^{\mathrm{a}}$ & 47 & $0,779^{\mathrm{a}}$ \\
\hline 14 & $0,642^{\mathrm{a}}$ & 31 & $0,793^{\mathrm{a}}$ & 48 & $0,716^{\mathrm{a}}$ \\
\hline 15 & $0,504^{\mathrm{a}}$ & 32 & $0,676^{\mathrm{a}}$ & 49 & $0,796^{\mathrm{a}}$ \\
\hline 16 & $0,759^{a}$ & 33 & $0,833^{\mathrm{a}}$ & 50 & $0,642^{\mathrm{a}}$ \\
\hline 17 & $0,488^{\mathrm{a}}$ & 34 & $0,783^{a}$ & & \\
\hline
\end{tabular}

Based on Table 1, the anti-image correlation value for all items is more than 0.4. Therefore, it can be concluded that 50 items of statement on the questionnaire of interest in becoming a teacher proved valid in the validity of the construct.

Furthermore, the analysis factor is followed by the interpretation of the eigen value of the variance covariance correlation matrix to find out how many factors are measured in the questionnaire of interest in becoming a teacher. The results of the analysis of the 
factors of interest in becoming a teacher are presented in Table 2.

Table 2. Results Analysis Factors of Interest in Becoming a Teacher

\begin{tabular}{|c|c|c|c|}
\hline \multirow{2}{*}{ No. } & \multicolumn{3}{|c|}{ Initial Eigenvalues } \\
\cline { 2 - 4 } & Total & \% of Variance & Comulative \% \\
\hline 1 & 3,780 & 22,442 & 22,442 \\
\hline 2 & 1,498 & 8,890 & 31,332 \\
\hline 3 & 0,879 & 5,325 & 36,657 \\
\hline 4 & 0,756 & 4,491 & 41,148 \\
\hline 5 & 0,749 & 4,446 & 45,594 \\
\hline
\end{tabular}

In addition to proving the validity of instrument constructs, factor analysis is also used to analyze relationships between variables using correlation tests so that new variables that are obtained are called factors. Based on the results of the factor analysis in Table 2, there are 2 eigen values greater than 1 . Eigen values greater than 1 are mentioned as factors, so the poll of interest in becoming a teacher contains two factors $[4,38]$. The two factors can explain $31.332 \%$ of the total variance so it can be said that the questionnaire of interest in becoming a teacher can explain $31.332 \%$ of students' interest in becoming teachers.

The results of the factor analysis are also visualized with a scree plot to clarify the picture of the eigen value presented in Figure 1. Figure 1 shows the eigen value starting to ramp up at factor 3 , so there is one dominant factor measured by the questionnaire instrument which is the interest in becoming a teacher and another factor that also contributes considerable contribution to the instrument's response. Although the poll's interest in becoming a teacher contains two factors, there is one dominant factor measured [3]. The dominant factor is the interest in becoming a teacher because this questionnaire was developed based on the description of the interest indicator. At the same time, one other factor that is measured in this instrument is the perception factor of the teacher profession. This factor is measured because several statements position students as a teacher to respond to statements about problems that often occur in schools.

\section{Scree Plot}

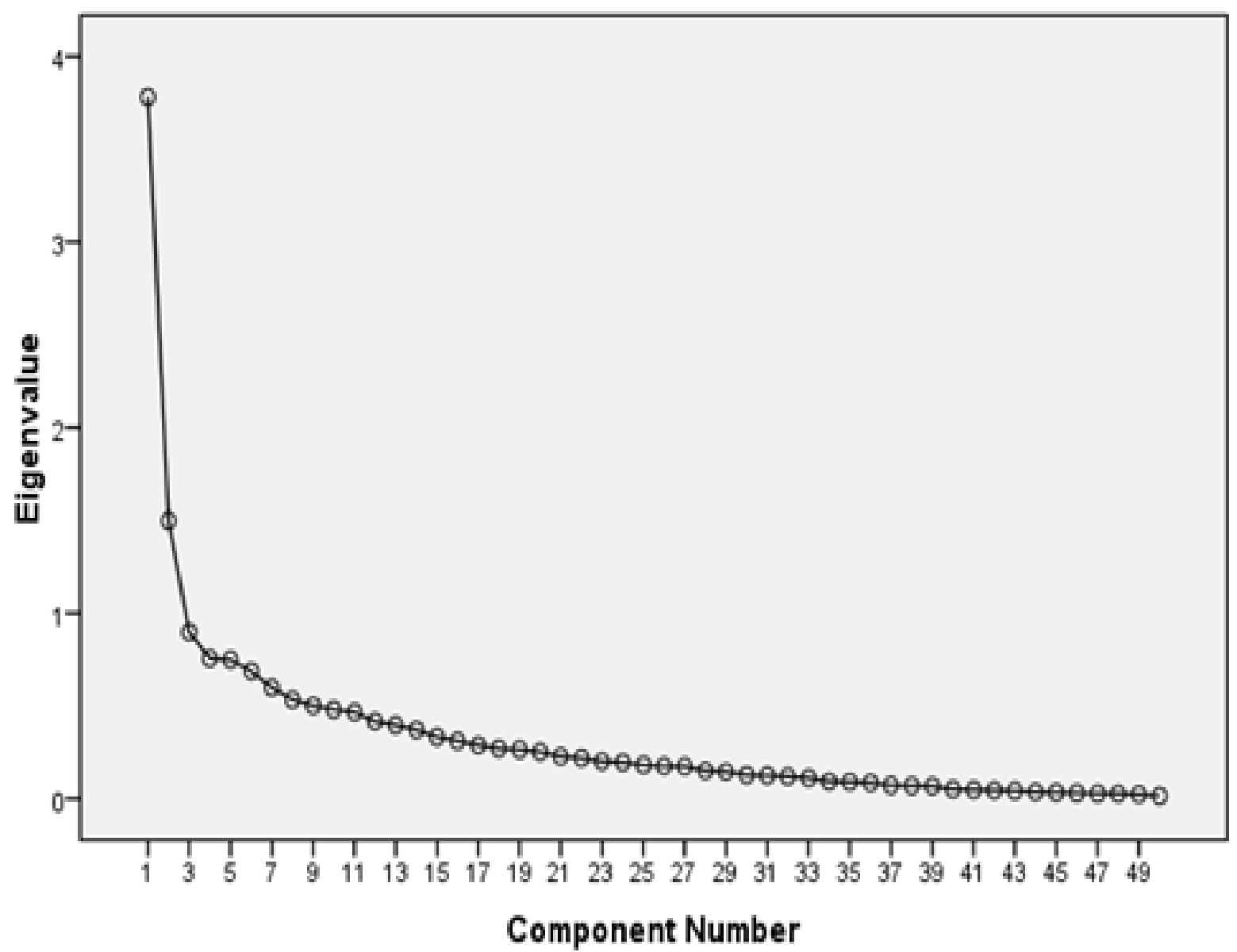

Figure 1. Scree Plots Questionnaire Interest in Becoming a Teacher 
The dominance factor measured by an instrument indicates that the instrument is unidimensional. Unidimensional is a trait of an instrument that measures only one dimension or one variable [23]. Unidimension is often referred to as the validity of the construct because when unidimension is fulfilled, the validity of the construct is also proven. The construct validity of an instrument is proven if it measures only one variable. The condition of an instrument is said to be unidimensional if the instrument has one dominant factor and the first factor of the exploratory factor analysis has a communrative percent of more than $20 \%$ [9, 23, 29, 37]. According to the statement, it can be said that the instrument of interest questionnaire is unidimensional because it has one dominant factor and has a first-factor cumulative percent of $22.442 \%$. Therefore, the questionnaire of interest in becoming a teacher has proven valid in the validity of the construct because it only measures one dimension, i.e. the dimensions of interest as well as all the statement items in the instrument of the questionnaire no one died.

Analysis of the questionnaire's reliability is used to determine the accuracy of the questionnaire in providing measurement results. Reliable questionnaires will provide relatively similar measurement results when tested over and over again in different samples. The reliability index is determined by Cronbach Alpha as statistical evidence to determine the instrument's internal consistenty [6, 31]. Analysis of the reliability of the questionnaire instrument shows that the questionnaire instrument has a Cronbach Alpha of 0.922 with a variance error of 0.15 (0.922 $0.922=0.85 ; 1.00-0.85=0.15)$. Cronbach Alpha of 0.922 $(\alpha>0.900)$ means that the instrument has excellent internal consistency [32]. Based on these results, Cronbach Alpha's value for the instrument of interest in becoming a teacher is very high. Cronbach Alpha's very high value is due to some statements containing almost the same statement but with different sentences [32]. Similar statements are used in anticipation of a fall statement when in a construct validity test, so some statements are composed based on the same indicators, but are poured in different sentences. Therefore, the reliability of the test is not separated from the validity of the measurement.

The results of the reliability test also revealed an error in the measurement of individual scores of the test takers [13]. Measurement errors are expressed in SEM or Measurement Default Errors. SEM estimates are used to determine the difference between an individual's score on a test and the actual score [32]. Cronbach Alpha of 0.922 causes a measurement default error of 2.2. The larger the Cronbach Alpha value, the smaller the SEM value. If the test has high consistency, then the measurement error caused by the use of the test instrument is relatively small. Such measurement errors can be caused by two main factors, namely internal and external factors. External factors include situations during the test such as room temperature, guessing answers, emotional problems while working, physical discomfort and sleep deprivation while internal factors include the number of statements in the test instrument and scoring system [2]. According to the statement, the instrument of interest in becoming a teacher has very good test reliability resulting in relatively small measurement errors.

\subsection{Difference in Interest in Becoming Chemistry Teacher between Chemistry Education Student and Chemistry Student}

To determine whether there is a difference of interest between the three groups mentioned, statistically hypothetical testing was conducted. The hypothesis was tested using One-Way Anova to determine whether there was a difference in interest in being a teacher in all three sample groups. The variables tied in this study were the interest of being a teacher, whereas the free variables in this study were groups of students who came from three different studies. Before the hypothesis test, the normality test and sample homogeneity test were firstly carried out $[11,28]$. This test was conducted as a pre-landing test to conduct hypothetical tests with One-Way Anova. The requirement to conduct a One-Way Anova test is that samples must come from normal and homogeneous distributed populations. Both assumptions must be met for the conclusions resulting from hypothetical testing to be accurate and reliable $[7,18]$. The normality test results are presented in Table 3.

Table 3. Normality Test Results

\begin{tabular}{|c|c|c|c|}
\hline \multirow{2}{*}{} & \multicolumn{3}{|c|}{ Kolmogorov-Smirnov } \\
\cline { 2 - 4 } & Statistic & df & Sig. \\
\hline \multirow{2}{*}{ Intention } & 0,076788 & 98 & 0,1768215 \\
\hline & \multicolumn{3}{|c|}{ Shapiro-Wilk } \\
\cline { 2 - 4 } & Statistic & df & Sig. \\
\hline Intention & 0,9810485 & 98 & 0,1698568 \\
\hline a. Lilliefors Significance Correction \\
\hline
\end{tabular}

Based on the normality test results both Kolmogorov-Smirnov and Shapiro-Wilk test results obtained a p>0.05 value so it can be said that the measurement results data is distributed normally [7]. If the sample of measurement data is normally distributed, the sample comes from a normally distributed population. Next, a homogeneity test is conducted to see if the measurement data comes from a homogeneous population. Homogeneity test results are presented in Table 4.

Table 4. Homogenity Test Result

\begin{tabular}{|c|c|c|c|}
\hline Levene Statistic & df1 & df2 & Sig. \\
\hline 0,344 & 2 & 95 & 0,71 \\
\hline
\end{tabular}

Based on the homogeneity test result, the Levene test obtains $p>0.05$, so it can be said that the measurement data comes from a homogeneous population. Since two 
parametric statistical test assumptions have been fulfilled, the hypothesis test can be done with the One-Way Anova test. Anova's One-Way test results are presented in Table 5.

Table 5. One-Way Anova Result

\begin{tabular}{|c|c|c|c|c|c|}
\hline & $\begin{array}{c}\text { Sum of } \\
\text { Squares }\end{array}$ & df & $\begin{array}{c}\text { Mean } \\
\text { Square }\end{array}$ & F & sig. \\
\hline $\begin{array}{c}\text { Between } \\
\text { Groups }\end{array}$ & 2174,544 & 2 & 1087,2718 & 6,297 & 0,003 \\
\cline { 1 - 4 } $\begin{array}{c}\text { Within } \\
\text { Groups }\end{array}$ & 16402,08 & 95 & 172,65346 & & \\
\hline Total & 18576,62 & 97 & & & \\
\hline
\end{tabular}

Based on the results of the One-Way test Anova, a value of $\mathrm{p}<0.05$ is obtained, so that it can be stated that H0 was rejected [30]. Therefore, based on the hypothesis test, it was concluded that there was a difference in interest in becoming a teacher among the three sample groups.

Anova's One-Way test is only used to determine whether there is a difference in interest in being a teacher between the three groups, so it is necessary to do a different pairwise test [15]. Post hoc tests are conducted to find out which group has the highest interest in becoming teachers and vice versa. The post hoc test used is the Scheffe test. The scheffe test results are presented in Table 6.

Based on the mean difference of the scheffe test results, group 3 has an enormous mean difference when compared to the other two groups, so group 3 has a greater interest in becoming teachers than the other two groups. Furthermore, group 2 has a greater mean difference compared to group 1, so the group of students who have the lowest interest in becoming teachers is group 1. Based on the description, the order of interest to become the third teacher of the group is students of the LPTK Chemical Education Program > students of the LPTK Chemical Program > non-LPTK Chemistry Students.

The amount of interest that students have in chemistry education to become a teacher can be persuaded by several factors including teaching readiness and confidence to be a professional teacher. These two dominant factors are the main foundations that prospective teachers must have. Vaninni [35] revealed that the readiness to teach a prospective teacher student began to be built from the beginning of the lecture process through his mastery of science and teaching experience. Students of the Chemical Education Program are more often in contact and concentrate on the situation of teaching and learning, compared to students of the Chemistry Program. Therefore, students' interest continues to increase as the learning process progresses.

Environmental factors are also one of the extrinsic factors that affect students' interest. Although it has similarities in studying chemistry and developing professional competencies, it does not mean there is an interest for non-educational students to demonstrate the knowledge that they have to others (learners). The university environment also causes higher interest in LPTK chemistry students compared to non-LPTK because students of LPTK chemistry program more often interact with students of the Chemistry Education Program, so as to influence the perception of students of LPTK Chemistry Program about the teacher profession.

Education students are trained to have good personality competencies through mastery of educational psychology. Through these learning activities, students are expected to improve their self-quality in order to have a good psychological dimension [12]. Mkhdramine \& Essafi [17] asserts that this personality competency is important for prospective students to have because it will later affect the quality of learning. Basically the learning process and activities of teaching are part of the social process, so it makes sense if personality and social competencies must be owned by prospective students so that the learning process that is implemented later becomes more effective.

Table 6. Scheffe Test Result

\begin{tabular}{|c|c|c|c|c|c|c|}
\hline \multirow{2}{*}{ (I) Class } & \multirow{2}{*}{ (J) Class } & \multirow{2}{*}{ Mean Difference (I-J) } & \multirow{2}{*}{ Std. Error } & \multirow{2}{*}{ Sig. } & \multicolumn{2}{|c|}{ 95\% Confidence Interval } \\
\hline & & & & & Lower Bound & Upper Bound \\
\hline \multirow{2}{*}{1} & 2 & $-11.263^{*}$ & 3.520 & 0.008 & -20.02 & -2.51 \\
\hline & 3 & $-11.316^{*}$ & 3.520 & 0.007 & -20.07 & -2.56 \\
\hline \multirow{2}{*}{2} & 1 & $11.263^{*}$ & 3.520 & 0.008 & 2.51 & 20.02 \\
\hline & 3 & -0.053 & 3.014 & 1.000 & -7.55 & 7.44 \\
\hline \multirow{2}{*}{3} & 1 & $11.316^{*}$ & 3.520 & 0.007 & 2.56 & 20.07 \\
\hline & 2 & 0.053 & 3.014 & 1.000 & -7.44 & 7.55 \\
\hline
\end{tabular}


Some of the research that has been done also highlights how important social influence is. Students' interest in becoming teachers can be formed since they are still in secondary school, and then reinforced by the university environment, namely lecturers and universities. In addition, parents can also influence students' interests. The interest of students of the Chemistry Education Program can grow because of its strong desire to be a role model for students through the motivation given by lecturers and intense interaction with friends in one program [20,33, 35]. Meanwhile, the low interest of non-LPTK Chemistry Students can be caused by an unsupportive learning environment to be able to learn deeper learning systems.

Curriculum differences compiled by LPTK and non-LPTK are also one of the extrinsic factors that influence students' interest in becoming teachers. LPTK opens up a great opportunity for its students to explore the world of education through pedagogical courses provided. In addition, LPTK also facilitates educational students to experience teaching [20]. The curriculum developed is able to be a platform to develop pedagogical, professional, personality, and social competencies. Based on the draft curriculum of teacher and college training institutions, one of the skills that must be trained to teacher to improve their teaching competencies is teaching skills [40]. Therefore, through the various processes that have been carried out, students of the Chemical Education Program can grow the interest to become teachers when compared to students of LPTK chemistry program and non-LPTK.

\section{Conclusions}

It can be concluded from the research that has been done on 98 students that there is a difference in students' interest in becoming teachers. Students of LPTK Chemical Education Program have the most interest, which is followed by students of LPTK Chemistry Program, while non-LPTK Chemistry students have a low interest in becoming teachers.

\section{REFERENCES}

[1] Afrianto, "Being a Professional Teacher in the Era of Industrial Revolution 4.0: Opportunities, Challenges and Strategies for Innovative Classroom Practices,” English Language Teaching and Research, Vol. 2, No. 1, pp. 1-13, 2018.

[2] Anastasi, A., \& Urbina, S, "Psychological testing 7th edition,” Upper Sadder River: Prentice Hall, 1997.

[3] Beavers, A. S., Lounsbury, J. W., \& Richard, J. K., "Practical considerations for using exploratory factor analysis in educational research," Practical Assessment, Research \& Evaluation, Vol. 18, No. 6, pp. 1-13, 2013.
[4] Braeken, J., \& van Assen, M. A., “An empirical kaiser criterion," Psychological Methods, Vol. 22, No. 3, pp. 450-466, 2017. DOI: 10.1037/met0000074

[5] Chan, L. L., \& Idris, N., "Validity and reliability of the instrument using exploratory factor analysis and cronbach's alpha," International Journal of Academic Research in Business and Social Sciences, Vol. 7, No. 10, pp. 400-410, 2017. DOI: 10.6007/IJARBSS/v7-i10/3387

[6] Cronbach, L. J., "Coefficient alpha and the internal structure of tests,” Psychometrika, Vol. 16, No. 3, pp. 297-334, 1951.

[7] Ghasemi, A., \& Zahediasl, S., "Normality tests for statistical analysis: a guide for non-statisticians," International Journal of Endocrinology \& Metabolism, Vol. 10, No. 2, pp. 486-489, 2012. DOI: 10.5812/ijem.3505

[8] Hair, J. H., Black, W. C., Babin, B. J., \& Anderson, R., "Mutivariate Data Analysis 7th Edition," Upper Saddle River: Pearson, 2009.

[9] Hambleton, R. K., Swaminathan, H., \& Rogers, H. J., "Fundamentals of item response theory,” Los Angeles: Sage Publications, 1991.

[10] Hussin, A. A., "Education 4.0 Made Simple: Ideas for Teaching,” International Journal of Education and Literacy Studies, Vol. 6, No. 3, pp 92, 2018. DOI: 10.7575/aiac.ijels.v.6n.3p.92

[11] Kim, Y. J., \& Cribbie, R. A., "ANOVA and the variance homogeneity assumption: exploring a better gatekeeper," British Journal of Mathematical and Statistical Psychology, Vol. 71, No. 1, pp. 1-25, 2017. DOI: 10.1136/bmj.311.7003.485

[12] Kurt, M., \& Karamustafaoğlu, O., "Determining the Preservice Teachers' Motivation and Attitudes towards Teaching Profession,” IOSR Journal of Research \& Method in Education (IOSR-JRME), Vol. 8, No. 1, pp. 38-46, 2018. DOI: $10.9790 / 7388-0801013846$

[13] Livingston, S. A., “Test reliability-basic concepts," Princeton: ETS, 2018.

[14] Mansilla, V. B., \& Jackson, A., "Education for Global Competence: Preparing Our Youth to Engage the World," Asia Society, 2011.

[15] McHugh, M. L., "Multiple comparison analysis testing in ANOVA”. Biochemia Medica, Vol. 21, No. 3, pp. 203-209, 2011. DOI: 10.11613/BM.2011.029

[16] Mergler, A. G., \& Spooner-Lane, R. "What Pre-service Teachers Need to Know to be Effective at Values-based Education,” Australian Journal of Teacher Education, Vol. 37, No. 8, pp. 66-81, 2012. DOI: 10.14221/ajte.2012v37n8.5

[17] Mkhdramine, S., \& Essafi, K., "First Year Student Perceptions of Teacher and Teaching Effectiveness a New Approach in the Evaluation of Educational Process,” Journal of Research \& Method in Education, Vol. 6, No. 6, pp. 5562, 2016. DOI: 10.9790/7388-0606045562

[18] Oztuna, D., Elhan, A. H., \& Tuccar, E. “Investigation of four different normality test in terms of type 1 error rate and power under different distributions," Turkish Journal of Medical Sciences, Vol. 36, No. 3, pp. 171-176, 2006. 
[19] PDDIKTI. "Statistik Perguruan Tinggi 2018. In Kementerian Riset dan Perguruan Tinggi: Vol. PT-18," (Issue 001.003). https://pddikti.ristekdikti.go.id/asset/data/p ublikasi/StatistikPendidikanTinggiIndonesia 2018.pdf, 2018.

[20] Powers, A., “Teacher Preparation for Environmental Education: Faculty Perspectives on the Infusion of Environmental Education into Preservice Methods Courses”. In U.S. Environmental Protection Agency's National Network of Environmental Management Studies, Vol. 35, No. 3, 2004.

[21] http://www.peecworks.org/PEEC/PEEC_Research/01795C 12-001D0211.0/Powers teacher prep.pdf

[22] Puncreobutr, V., "Education 4.0: New Challenge of Learning," Journal of Humanities and Social Sciences, Vol. 2, No. 2, pp. 92-97, 2016. DOI: 10.7575/aiac.ijels.v.6n.3p.9

[23] Reckase, M. D. "Unifactor laten trait models applied to multifactor tests: results and implications," Journal of Educational Statistics, Vol. 4, No. 3, pp. 207-230, 1979. DOI: 10.3102/10769986004003207

[24] Republik Indonesia, “Undang-undang No 14 Tahun 2005 Tentang Guru dan Dosen, Jakarta: Kementerian Pendidikan dan Kebudayaan, 2005.

[25] Republik Indonesia, "Peraturan Pemerintah No 74 Tahun 2008 Tentang Guru,” Jakarta: Kementerian Pendidikan dan Kebudayaan, 2008.

[26] Republik Indonesia, "Permendikbud No 87 Tahun 2013 Tentang Pendidikan Profesi Guru Prajabatan,” Jakarta: Kementerian Pendidikan dan Kebudayaan, 2013.

[27] Republik Indonesia. "Permendikbud No 22 Tahun 2020 Tentang Rencana Strategis Kementerian Pendidikan dan Kebudayaan Tahun 2020-2024,” Jakarta: Kementerian Pendidikan dan Kebudayaan, 2020.

[28] Sharma, D., \& Kibria, B. G., "On some test statistics for testing homogeneity of variances: a comparative study," Journal of Statistical Computation and Simulation, Vol. 83, No. 10, pp. 1944-1963, 2012. DOI: 10.1080/00949655.201 2.675336

[29] Smits, N., Cuijpers, P., \& van Straten, A., “Applying computerized adaptive testing to the CES-D scale: A simulation study," Psychiatry Research, Vol. 188, pp. 147-155, 2011. DOI: 10.1016/j.psychres.2010.12.001

[30] Sow, M. T., "Using ANOVA to examine the relationship between safety \& security and human development,” Journal of International Business and Economics, Vol. 2, No. 4, pp. 101-106, 2014. DOI: 10.15640/jibe.v2n4a6

[31] Taber, K. S., “The use of Cronbach’s alpha when developing and reporting research instruments in science education," Research in Science Education, Vol. 48, pp. 1273-1296, 2018. DOI: 10.1007/S11165-016-9602-2

[32] Tavakol, M., \& Dennick, R., "Making sense of Cronbach’s alpha,” International Journal of Medical Education, Vol. 2, pp. 53-33, 2011. DOI: 10.5116/ijme.4dfb.8dfd

[33] Topkaya, E. Z., \& Uztosun, M. S., “Choosing Teaching as a Career: Motivations of Pre-service English Teachers in Turkey,” Journal of Language Teaching and Research, Vol. 3, No. 1, pp. 126-134, 2012. DOI: 10.4304/jltr.3.1.126-134

[34] Ugulu, I, “Confirmatory factor analysis for testing validity and reliability of traditional knowledge scale to measure university students' attitudes,” Educational Research and Review, Vol. 8, No. 16, pp. 1399-1408, 2013. DOI: 10.5897/ERR2013.1537

[35] Vannini, I., "Beliefs and Motivation to Teaching in Pre-service Teachers a Reasearch within The Students of the Pre-service University Degree Course for Pre-school and Primary School Teaching in the University of Bologna," Procedia-Social and Behavioral Sciences, Vol. 15, pp. 731737, 2011. DOI: 10.1016/j.sbspro.2011.03.174

[36] Weidmaier, B., “Post Hoc Tests”. In M. Allen, The SAGE Encyclopedia of Communication Research Methods (p. 3). Thousand Oaks: Sage Publications, 2017.

[37] Wu, Q., Zhang, Z., Song, Y., Zhang, Y., Zhang, F., Li, R., et al. "The development of mathematical test based on item response theory," International Journal of Advancements in Computing Technology, Vol. 5, No. 10, pp. 209-216, 2013. DOI: 10.26858/est.v6i2.13295

[38] Yeomans, K. A., \& Golder, P. A., "The Guttman-Kaiser Criterion as a predictor of the number of common factors," Journal of the Royal Statistical Society. Series D (The Statistician), Vol. 31, No. 3, pp. 221-229, 1982. DOI: $10.2307 / 2987988$

[39] Yu, T., \& Richardson, J. C., “An exploratory factor analysis and reliability analysis of the student online learning readiness (SOLR) instrument," Online Learning Journal, Vol. 19, No. 5, pp 120-141, 2015. DOI: 10.24059/olj.v19i5.593

[40] Teresa F. Blanco, Juan D. Godino, Pablo G. Sequeiros, Jose Manuel Diego-Mantecón., "Skill Levels on Visualization and Spatial Reasoning in Pre-service Primary Teachers," Universal Journal of Educational Research, Vol. 7, No. 12, pp. 2647 - 2661, 2019. DOI: 10.13189/ujer.2019.071212.

[41] S. Chee Choy, Joanne Sau Ching Yim, Daljeet Singh Sedhu., "Pre-service Teachers' Reflection on Reflective Practices: A Malaysian Perspective," Universal Journal of Educational Research, Vol. 7, No. 12A, pp. 18 - 26, 2019. DOI: 10.13189/ujer.2019.071903. 